Cowan, N.J.; Levy, P.E.; Famulari, D.; Anderson, M.; Reay, D.S.; Skiba, U.M.. 2017. Nitrous oxide emission sources from a mixed livestock farm. Agriculture, Ecosystems and Environment, 243. 92-102. https://doi.org/10.1016/i.agee.2017.04.014

(C) 2017 Elsevier B.V.

This manuscript version is made available under the CC-BY-NC-ND 4.0

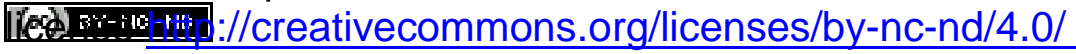

This version available http://nora.nerc.ac.uk/id/eprint/517958/

NERC has developed NORA to enable users to access research outputs wholly or partially funded by NERC. Copyright and other rights for material on this site are retained by the rights owners. Users should read the terms and conditions of use of this material at http://nora.nerc.ac.uk/policies.html\#access

NOTICE: this is the author's version of a work that was accepted for publication in Agriculture, Ecosystems and Environment. Changes resulting from the publishing process, such as peer review, editing, corrections, structural formatting, and other quality control mechanisms may not be reflected in this document. Changes may have been made to this work since it was submitted for publication. A definitive version was subsequently published in Agriculture, Ecosystems and Environment, 243. 92-102. https://doi.org/10.1016/j.agee.2017.04.014

www.elsevier.com/ 


\section{Nitrous oxide emission sources from a mixed livestock farm}

2 Authors: N. J. Cowan ${ }^{\text {a, b }}$, P. E. Levy ${ }^{\text {a }}$, D. Famulari ${ }^{a}$, M. Anderson ${ }^{\text {a }}$, D. S. Reay ${ }^{\text {b }, ~ U . ~ M . ~ S k i b a ~}{ }^{\text {a }}$

$3{ }^{a}$ Centre for Ecology and Hydrology, Bush Estate, Penicuik, Edinburgh, EH26 0QB

$4 \quad \mathrm{~b}$ School of Geosciences, Kings Buildings, University of Edinburgh, Edinburgh, EH9 3JG

$5 \quad$ Corresponding Author: Nicholas Cowan (nicwan11@ceh.ac.uk)

\section{Abstract}

7 The primary aim of this study was to identify and compare the most significant sources of nitrous oxide $\left(\mathrm{N}_{2} \mathrm{O}\right)$

8 emissions from soils within a typical mixed livestock farm in Scotland. The farm area can be considered as 9 representative of agricultural soils in this region where outdoor grazing forms an important part of the animal 10 husbandry. A high temporal resolution dynamic chamber method was used to measure $\mathrm{N}_{2} \mathrm{O}$ fluxes from the 11 featureless, general areas of the arable and pasture fields (general) and from those areas where large nitrogen 12 additions are highly likely, such as animal feeding areas, manure heaps, animal barns (features). Individual $\mathrm{N}_{2} \mathrm{O}$ 13 flux measurements varied by four orders of magnitude, with values ranging from -5.5 to $80,000 \mu \mathrm{g} \mathrm{N}_{2} \mathrm{O}-\mathrm{N} \mathrm{m}^{-2} \mathrm{~h}^{-}$

14 . The log-normal distribution of the fluxes required the use of more complex statistics to quantify uncertainty, 15 including a Bayesian approach which provided a robust and transparent method for "upscaling" i.e. translating 16 small-scale observations to larger scales, with appropriate propagation of uncertainty. Mean $\mathrm{N}_{2} \mathrm{O}$ fluxes 17 associated with the features were typically one to four orders of magnitude larger than those measured on the 18 general areas of the arable and pasture fields. During warmer months, when widespread grazing takes place across 19 the farm, the smaller $\mathrm{N}_{2} \mathrm{O}$ fluxes of the largest area source - the general field (99.7\% of total area) - dominated the 20 overall $\mathrm{N}_{2} \mathrm{O}$ emissions. The contribution from the features should still be considered important, given that up to $2191 \%$ of the fluxes may come from only $0.3 \%$ of the area under certain conditions, especially in the colder winter 22 months when manure heaps and animal barns continue to produce emissions while soils reach temperatures 23 unfavourable for microbial activity $\left(<5^{\circ} \mathrm{C}\right)$.

24 Keywords: Farm scale, greenhouse gas, upscaling, nitrogen 


\section{Introduction}

Nitrous oxide $\left(\mathrm{N}_{2} \mathrm{O}\right)$ is a powerful greenhouse gas, which also contributes to stratospheric ozone depletion (Intergovernmental Panel on Climate Change, 2014; Ravishankara et al., 2009). Microbially mediated nitrification and denitrification pathways in soils and aquatic environments are the primary sources of $\mathrm{N}_{2} \mathrm{O}$ (Butterbach-Bahl et al., 2013; Davidson et al., 2000). The increase in livestock numbers (Thornton, 2010) and large-scale application of nitrogen fertilisers to agricultural soils over the past 100 years have contributed to large increases in concentrations of reactive nitrogen in the environment (Fowler et al., 2013). This has resulted in a significant increase in anthropogenic $\mathrm{N}_{2} \mathrm{O}$ emissions at a global scale (Reay et al., 2012).

Quantifying agricultural $\mathrm{N}_{2} \mathrm{O}$ emissions at large scales has proven difficult due to the uncertainties involved in measuring $\mathrm{N}_{2} \mathrm{O}$ fluxes (Cowan et al., 2015; Giltrap et al., 2014; Mathieu et al., 2006), the multiple environmental factors which influence $\mathrm{N}_{2} \mathrm{O}$ production at a microbial level (Butterbach-Bahl et al., 2013; Thomson et al., 2012) and in accounting for the effects of a wide variety of farm management practices which alter the natural nitrogen cycle. The complex heterogeneous nature of agricultural soils presents a challenge when it comes to identifying which microbiological processes (i.e. denitrification, nitrifier denitrification, chemodenitrification, nitrification) are contributing to $\mathrm{N}_{2} \mathrm{O}$ emissions. These processes may occur simultaneously within microsites of the same soil (Baggs, 2008), the rates of which may be independently controlled by a multitude of different environmental factors (e.g. temperature, soil moisture content, availability of organic carbon) (Bateman and Baggs, 2005; Davidson, 1992). The availability of mineralised nitrogen (predominantly ammonium $\mathrm{NH}_{4}{ }^{+}$and nitrate $\mathrm{NO}_{3}{ }^{-}$) is known to be a significant driver of $\mathrm{N}_{2} \mathrm{O}$ production from agricultural soils, but this relationship is unpredictable and can be influenced significantly by a wide spectrum of spatial and temporal environmental variables (Cowan et al., 2015; Kim et al., 2013; Shcherbak et al., 2014).

Previous experiments have been carried out with the goal of quantifying $\mathrm{N}_{2} \mathrm{O}$ emissions from individual farms with some success (Brown et al., 2001; Ellis et al., 2001; Flessa et al., 2002; Velthof and Oenema, 1997). Due to the complexity and magnitude of the task, these studies often focus on a particular aspect of $\mathrm{N}_{2} \mathrm{O}$ emissions from agricultural sources such as animal waste management (Chadwick et al., 1999), fertiliser use (Brown et al., 2001; Ma et al., 2010) or secondary emissions caused by leaching losses from soils (Reay et al., 2009). Lesser quantified sources of $\mathrm{N}_{2} \mathrm{O}$ such as ditches, gateways and feeding troughs are also potentially large emitters (Cowan et al., 2015; Matthews et al., 2010), but are not always accounted for in current $\mathrm{N}_{2} \mathrm{O}$ inventories due to a lack of available measurement data. In order to effectively manage and mitigate agricultural emissions of $\mathrm{N}_{2} \mathrm{O}$ it is 

of high $\mathrm{N}_{2} \mathrm{O}$ flux sources may increase our ability to mitigate farm scale emissions by identifying simple farm management practices that have a positive impact.

The vast majority of studies into agricultural sources of $\mathrm{N}_{2} \mathrm{O}$ have used chamber methodology to measure

fluxes. These measurements typically show a highly skewed, approximately log-normal distribution, with a small number of very high values (Cowan et al., 2015: Folorunso and Rolston, 1984; Velthof et al., 1996; Yanai et al., 2003). To infer the total flux from a whole field (i.e. the population of interest which has been sampled), the integral of the estimated log-normal distribution over the field is simply given by the mean flux $(\mu)$ multiplied by the area of the field. However, $\mu$ is poorly estimated by the arithmetic mean of the samples, because of its sensitivity to outliers. $\mu$ is therefore often highly uncertain, but estimating the uncertainty in the arithmetic mean of log-normally distributed data is problematic (Land, 1972). The density of a log-normally-distributed variate, $x$, is given by:

$$
d=1 /\left(\sqrt{(2 \pi)} \sigma_{\log } x\right) \exp \left(-\left(\left(\log (x)-\mu_{\log }\right)^{2} /\left(2 \sigma_{\log }^{2}\right)\right)\right)
$$

where $\mu_{\log }$ and $\sigma_{\log }$ are the mean and standard deviation of the log-transformed variate. The mean of the distribution (i.e. without log transformation) is given by:

$$
\mu=\exp \left(\mu_{\log }+0.5 \sigma_{\log }^{2}\right)
$$

Estimates of the parameters of the underlying log-normal distribution, $\mu_{\log }$ and $\sigma_{\log }$ (and thereby the true value of $\mu$ ), are often poor because of small sample size, measurement error and large variability. In order to better predict fluxes at the field or farm scale we therefore need a sound method for quantifying the uncertainty in $\mu$ which arises in estimating whole-field-scale fluxes from a small, log-normally distributed sample. Several methods have been proposed previously for calculating confidence intervals for the mean of a log-normally distributed variable (El Shaarawi and Lin, 2007; Land, 1972; Parkin et al., 1990). However, with small sample sizes and/or large variability, these methods are often unsatisfactory, and can result in implausibly large intervals (Zou et al., 2009).

The primary aim of this study was to identify and compare the most significant sources of $\mathrm{N}_{2} \mathrm{O}$ emissions from a typical livestock farm in Scotland, with a focus on $\mathrm{N}_{2} \mathrm{O}$ emissions from sources which are not associated directly with nitrogen fertiliser application, since the latter are already well-documented. A secondary aim was to examine the chemical properties of the soils in locations from which flux measurements were made in order to explain the variability in $\mathrm{N}_{2} \mathrm{O}$ emissions across the wide range of soil environments sampled across the farm. Our 
84 third aim was to investigate methods for upscaling point measurements to estimate whole-farm emissions and the 85 associated uncertainties using a Bayesian approach. 


\section{Materials and methods}

\subsection{Farm description}

The Easter Bush Farm Estate is a combination of several farms near Penicuik, Midlothian in Central Scotland

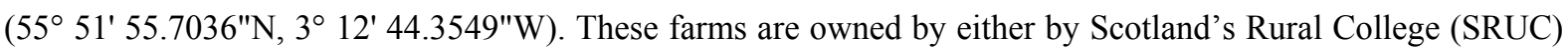
or the University of Edinburgh (UoE) and are run for commercial and research purposes. A selection of twenty separate fields where chosen which represented the wide variety of management practices within the estate and which were readily accessible for our flux measurement equipment. These fields covered approximately 133 ha of land and were chosen to represent a typical Scottish livestock farm in this study (Table 1). Fields were either used for growing arable crops for fodder (barley, oilseed rape, or silage grass) or as grazing pasture for sheep or cattle. The farm managers at the estate estimated that the selected fields and sheltered barns would provide for 440 ewes with 835 lambs and 86 cattle with 60 calves over the period of a year. The perimeter and area of each field was measured manually using a handheld GPS device (Garmin eTrex Legend HCx, Garmin, Shaffhausen, Switzerland).

\subsection{Quantification of $\mathrm{N}_{2} \mathrm{O}$ source area coverage}

101 Using GPS measurements, we estimated the total area coverage of each of the arable and grazed fields each season

102 to within $\pm 10 \%$. The area coverage of the farm was fairly evenly split between arable and grazing use (Table 2 ).

103 Some of the larger grass fields were switched between livestock grazing and silage grass (arable) for several

104 months at a time (see Table 1). Cattle were moved between barns and pasture, whereas the sheep spent all year 105 round in the fields. Our measurements covered the general grazed grasslands and arable fields, and several smaller 106 features which we identified as potentially important sources of $\mathrm{N}_{2} \mathrm{O}$. These features were areas of the farm which 107 were used more intensively, and comprised: areas around animal feeding and drinking troughs; areas that had 108 recently been used for manure storage; disturbed areas e.g. near gates or recently tilled; manure heaps; the 109 concrete-floored barns which accumulated animal waste; and silage heaps. Calculation of the areas of these

110 features was more uncertain. For example, a single manure heap and surrounding area contaminated by the heap

111 covered an area of $532 \mathrm{~m}^{2}$, but the relative proportions changed seasonally as the heap grew in size (up to $3 \mathrm{~m}$

112 high) and was spread onto arable crops in autumn. The capacity of the bedding area of the animal barns was $\sim 2500$

$113 \mathrm{~m}^{2}$, but the area used by the cattle varied seasonally. This was relatively high in the autumn and winter months

$114(60-80 \%)$ and lower for the rest of the year $(\sim 20 \%)$. The silage heap was approximately $3.5 \mathrm{~m}$ tall and covered 115 a total of $300 \mathrm{~m}^{2}$ when full after harvesting in early autumn, but this was progressively reduced over the following 
116 year. The uncertainty in the area of these features was estimated to be $50 \%$, because of the difficulty involved in

117 accurately identifying the true area coverage by visual inspection. Based on these estimates, the features accounted

118 for approximately $0.3 \%$ of the total area of the farm.

\subsection{Meteorological conditions}

120 Air temperature and rainfall (tipping bucket) were monitored by a permanent meteorological monitoring station

121 at the farm. The meteorological data recorded from this site is assumed to be representative for the entire farm area throughout the inventory measurement period due to the relatively small distance between the fields and the monitoring station. Annual cumulative rainfall for the period between July 2012 and August 2013 was $962 \mathrm{~mm}$.

124 The average annual rainfall over the past ten years $(2001-2011)$ was $921 \mathrm{~mm}$, which suggested that rainfall 125 during the measurement period was fairly typical (Figure 1a). Daily temperatures recorded were considered typical during the year in which measurements took place (Figure 1b).

\subsection{Dynamic chamber flux measurements}

128 A high-precision dynamic closed chamber system (Cowan et al., 2014a) was deployed to measure $\mathrm{N}_{2} \mathrm{O}$ fluxes 129 during four seasonal measurement periods between autumn 2012 and summer 2013. A pump (SH-110, Varian

130 Inc, CA, USA) circulated air between the flux chamber $\left(71 \mathrm{~min}^{-1}\right)$ and a compact continuous wave quantum 131 cascade laser (QCL) gas analyser (CW-QC-TILDAS-76-CS, Aerodyne Research Inc., Billerica, MA, USA) over

132 a three minute period (as in (Cowan et al., 2014a). The QCL instrument (instrumental noise of $30 \mathrm{ppt}$ at $1 \mathrm{~Hz}$ )

133 was secured inside an off-road vehicle to allow mobile measurements, powered by a diesel generator. The chamber

134 (non-transparent, $39 \mathrm{~cm}^{2}$ diameter, height $26 \mathrm{~cm}$ and volume $0.03 \mathrm{~m}^{3}$ ) was placed onto circular stainless steel 135 collars which were inserted $5 \mathrm{~cm}$ into the soil several minutes prior to each measurement. Two 30-m lengths of $1363 / 8$ inch ID Tygon ${ }^{\circledR}$ tubing were attached to both the inlet of the QCL and the outlet of the pump. This provided 137 a $30 \mathrm{~m}$ radius from the vehicle in which the chamber could be placed (Cowan et al., 2015).

139 (Table 3). Measurement locations were chosen at random across the fields which were accessible for the mobile

140 flux measurement system. Wet weather, difficult terrain and availability of the QCL instrument were limiting 141 factors in the number of measurements that were possible during each measurement period and the areas in which 142 measurements could take place. Typically five or more flux measurements were made from different collars in 
each field, with some fields being investigated in greater detail. Very wet weather during autumn and winter

144 months reduced the number of measurements which could be made.

\subsection{Soil sampling and analysis}

146 Two types of soil samples were taken at 457 of the flux chamber measurement locations. Soil samples ( $5 \mathrm{~cm}$ deep)

147 were taken from within the chamber collar using a $2 \mathrm{~cm}$ wide corer immediately after a flux measurement was

148 complete. These soils were frozen to $-18{ }^{\circ} \mathrm{C}$ within six hours of collection until analysis up to two months later.

149 The wet samples were defrosted in a refrigerated room $\left(5^{\circ} \mathrm{C}\right)$ overnight prior to analysis of $\mathrm{pH}\left(\right.$ in $\left.\mathrm{H}_{2} \mathrm{O}\right)$ and

150 available nitrogen in the form of ammonium $\left(\mathrm{NH}_{4}{ }^{+}\right)$and nitrate $\left(\mathrm{NO}_{3}^{-}\right)$. The $\mathrm{pH}$ of the soil samples was measured

151 using the method outlined in (Rowell, 1994), p160). Ten grams of air dried soil was placed in a small plastic cup.

$15220 \mathrm{ml}$ of deionised $\mathrm{H}_{2} \mathrm{O}$ was added to the soil and the mixture was shaken and left for 60 minutes. A pH meter

153 (MP220, Mettler Toledo, Columbus, Ohio, USA) was used to measure $\mathrm{pH}$ in the soil solution.

Ammonium $\left(\mathrm{NH}_{4}^{+}\right)$and Nitrate $\left(\mathrm{NO}_{3}^{-}\right)$was extracted from the soil samples using $\mathrm{KCl}$ extraction as outlined in (Rowell, 1994), p 226). Soil (15 g) was added to a flask and mixed with $50 \mathrm{ml}$ of $1 \mathrm{M} \mathrm{KCl}$ solution.

156 The solution was shaken automatically using an orbital shaker for 60 minutes. The mixture was filtered using 2.5 $\mu \mathrm{m}$ filter paper (Fisherbrand, Hampton, New Hampshire, USA) and the solution was stored and frozen in $20 \mathrm{ml}$ plastic vials. Concentrations of $\mathrm{NH}_{4}{ }^{+}$and $\mathrm{NO}_{3}{ }^{-}$were measured using a Bran and Luebbe AutoAnalyser (SPX Flow Technology, Norderstedt, Germany).

Separate soil samples used to measure bulk density were also taken immediately after the flux measurement using a sharp metal cutting cylinder $(7.4 \mathrm{~cm}$ diameter, $5 \mathrm{~cm}$ deep) which was carefully inserted into

162 undisturbed soil. These soil samples were kept in a refrigerated room $\left(5^{\circ} \mathrm{C}\right)$ until oven drying (less than seven 163 days after sample collection). These samples were used to calculate soil moisture content (via oven drying at 100

$164{ }^{\circ} \mathrm{C}$ ) and also provided the dry soil mass. Bulk density was calculated by dividing the volume of the cutting ring by the mass of dry soil. A sub sample of the dried soils was taken to be ground (via ball milling) for elemental 166 analysis of total carbon and nitrogen content of the soil (vario EL cube, Elementar, Hanau, Germany). WFPS was calculated from the bulk density soil samples as described in (Rowell, 1994). 
170 The "leaps" package for the freely available statistical software R (R Core Team, 2013 ) was used to perform step171 wise regression to find the best-fitting model, based on the Akaike information criterion (AIC) (Lumley, 2015). 172 AIC is a measure of model goodness-of-fit derived from information theory, widely used in model selection 173 (Burnham and Anderson 2004). It is based on the model likelihood, penalised by model complexity, as measured 174 by the number of parameters. For a set of candidate models, the model with the lowest AIC value represents the 175 best choice, given the trade-off between model likelihood and complexity. Using this approach, we selected the model which provided the best fit to the $\mathrm{N}_{2} \mathrm{O}$ flux data, given the available explanatory variables.

\subsection{Statistical analysis and upscaling}

A Bayesian approach (Wild et al., 1996; Zellner, 1971) was applied to constrain the plausible range of the mean $\mathrm{N}_{2} \mathrm{O}$ flux. We carried out Markov Chain Monte-Carlo (MCMC) simulations using the freely-available JAGS software (Plummer, 2003) which implements Gibbs sampling to estimate the posterior distribution of $\mu$, by combining the prior with the data. We used an informative prior in the form of a log-normal distribution, with mean and variance based on the $\mathrm{N}_{2} \mathrm{O}$ fluxes predicted by the regression analysis described above. For each field/feature, we derived the relationship between $\mathrm{N}_{2} \mathrm{O}$ flux and soil nitrogen based on data from all the other fields/features, and used this to predict the expected distribution of $\mathrm{N}_{2} \mathrm{O}$ flux in the field/feature of interest. This allowed us to incorporate our knowledge of this functional relationship into our prior expectation of the $\mu_{\log }$ and $\sigma_{\log }$ parameters. Generally, the data dominate the posterior distribution, except where the data do not show a clear log-normal distribution, and so do not strongly constrain the fit of the $\mu_{\log }$ and $\sigma_{\log }$ parameters. Here, the prior acts to constrain values of $\mu$ to within the range expected, given the relationship with soil nitrogen, and thereby downweights implausibly high values of $\mu$. We did this for each of the source categories in Table 3 to estimate $\mu$, with $95 \%$ confidence intervals from the quantiles of the posterior distribution. For comparison, we also calculated the naïve sample mean and confidence intervals (i.e. based solely on the sample data), and also using the method outlined in (Zou et al., 2009) as implemented in the EnvStats package for R (Millard, 2016).

In our data set, fluxes varied unpredictably by five orders of magnitude over short distances $(<10 \mathrm{~m})$,

194 within all the features we identified and by four orders of magnitude for the general fields. We examined semivariograms for the $\mathrm{N}_{2} \mathrm{O}$ fluxes and ancilliary data, in which the semi-variance is plotted as a function of 196 distance between spatial points, using the GeoR package in R (Ribeiro, 2016). These showed no evidence of 
197 spatial autocorrelation in the data at any scale. Classical geostatistical interpolation methods, such as Kriging,

198 were therefore not applicable in spatial upscaling, and the whole field or feature-scale emission can be estimated

199 as $\mu$ multiplied by the field/feature area. In each season, the whole-farm emission estimates were calculated by

200 summing the emissions from all of the source categories. Uncertainty in the mean flux was propagated with the

201 uncertainty in the area of each source category by adding variances to provide the uncertainty in the whole-farm

202 emission. Due to the lack of measurements made in winter, we estimated emissions from sheep-grazed fields

203 based on a combination of both the arable and cattle fields during the same period. 


\section{1. $\mathrm{N}_{2} \mathrm{O}$ flux measurements}

207 Individual $\mathrm{N}_{2} \mathrm{O}$ flux measurements varied by five orders of magnitude, with values between -5.5 and $352,900 \mu \mathrm{g}$

$208 \mathrm{~N}_{2} \mathrm{O}-\mathrm{N} \mathrm{m}^{-2} \mathrm{~h}^{-1}$ (Figure 2). The log-normal distribution of the fluxes in the differently managed general field types

209 is fairly consistent across the farm (as observed in Figure 2). Fluxes from the features appeared to follow a log-

210 normal distribution, varying by up to five orders of magnitude. Fluxes measured from disturbed soils varied in

211 magnitude similar to the measurements on the general areas in the same fields, but also included some very high

212 fluxes $\left(>10,000 \mu \mathrm{g} \mathrm{N}_{2} \mathrm{O}-\mathrm{N} \mathrm{m}^{-2} \mathrm{~h}^{-1}\right)$. Fluxes measured from manure in the animal barns and outdoor manure heaps

213 were very variable, between 1 and $80,000 \mu \mathrm{g} \mathrm{N} \mathrm{N}_{2} \mathrm{O}-\mathrm{N} \mathrm{m}^{-2} \mathrm{~h}^{-1}$ and most were considerably higher than those

214 measured from the general field areas. We measured fluxes from the base of the manure heaps to the top (up to 3

$215 \mathrm{~m}$ high) and no relationship was observed between $\mathrm{N}_{2} \mathrm{O}$ flux and height of the manure heaps. Fluxes measured

216 from the stored silage grass at the farm also varied by five orders of magnitude. The single largest flux

217 measurement recorded from the entire farm area was from a decaying clump of wet grass at the bottom of the

218 silage heap in summer. This small pile of grass had begun to turn black and was coated with fungi. A single

219 extreme flux of $352,900 \mu \mathrm{g} \mathrm{N} \mathrm{N}_{2} \mathrm{O}-\mathrm{N} \mathrm{m}^{-2} \mathrm{~h}^{-1}$ was recorded from this small patch (approximately $40 \mathrm{~cm}^{2}$ in size) of

220 decomposing silage grass which had collected on a concrete surface for several weeks or months. This

221 measurement was excluded from the silage heap grouping as it was considered an oddity and not representative

222 of the remaining grass in the heap.

\subsection{Summary of all soil measurements}

Soil temperatures during flux measurement periods reached a minimum of $2{ }^{\circ} \mathrm{C}$ in winter and a maximum of $19{ }^{\circ} \mathrm{C}$ in summer (Table 4). Soil temperatures recorded in spring and autumn were similar (approximately $11{ }^{\circ} \mathrm{C}$ ). WFPS was generally higher in autumn and winter than it was in spring and summer, although this varied on a case to case basis due to topography, soil type and the varying condition of the field drainage systems present at measurement locations. Average $\mathrm{pH}$ values were fairly consistent across the fields in all seasons ( $\sim 6.4)$, although several individual measurements varied widely from this value (Figure 3). Bulk density varied across the farm with a maximum of $1.6 \mathrm{~g} \mathrm{~cm}^{-3}$, a minimum of $0.4 \mathrm{~g} \mathrm{~cm}^{-3}$ and an average value of $0.9 \mathrm{~g} \mathrm{~cm}^{-3}$. Individual measurements of total carbon and total nitrogen content of the soils across the farm varied widely from all sources; however, no patterns could be established between the different sources and seasons (Table 4). 
234 the general fields (Table 4). Available nitrogen concentrations were larger in all field types in spring and summer 235 than in winter and autumn. The log-normal distribution of both $\mathrm{NH}_{4}{ }^{+}$\& $\mathrm{NO}_{3}{ }^{-}$concentrations (Figure 4) were 236 similar to that of the $\mathrm{N}_{2} \mathrm{O}$ flux measurements (Figure 2). Like $\mathrm{N}_{2} \mathrm{O}$ fluxes, the individual available nitrogen 237 measurements also varied unpredictably by several orders of magnitude over short distances $(<10 \mathrm{~m})$. Available 238 nitrogen concentrations were considerably higher in the feeding area and manure contaminated soils than they 239 were in the general areas on the fields (Table 4).

\subsection{Relation between soil properties and $\mathrm{N}_{2} \mathrm{O}$ flux}

241 The correlations between individual $\mathrm{N}_{2} \mathrm{O}$ fluxes and soil properties are fairly poor (Figure 4). The strongest 242 correlation is observed between $\log$ (Flux) and $\log \left(\mathrm{NO}_{3}{ }^{-}\right)$, accounting for $41 \%$ in the variance of individual 243 measurements $(n=449)$. Grouping measurements that were taken from the same field/source on the same day 244 improves the correlation between flux and soil properties. The strongest correlation observed using this grouping 245 is also between $\log ($ Flux $)$ and $\log \left(\mathrm{NO}_{3}^{-}\right)$with 71 points explaining $62 \%$ of the variance. When grouping the data 246 based on each of the emission sources by the season in which they were measured (as in Table 4) the relationship 247 correlates strongest between $\log$ (Flux) and either $\mathrm{NO}_{3}{ }^{-}$or $\log \left(\mathrm{NH}_{4}{ }^{+}\right)$, both with relatively high $\mathrm{R}^{2}$ values of 0.86 .

248 In each of the groupings it is clear that $\mathrm{N}_{2} \mathrm{O}$ flux correlates considerably better with the soil available nitrogen

$249\left(\mathrm{NH}_{4}{ }^{+}\right.$and $\left.\mathrm{NO}_{3}{ }^{-}\right)$than with any of the other properties for which the univariate correlations are relatively weak in 250 this data set.

Using best-subsets regression, we select the model which best explains the variability in $\mathrm{N}_{2} \mathrm{O}$ fluxes,

252 based on the lowest AIC value (Table 5). For the individual chamber measurements univariate linear regression between $\log$ (Flux) and $\log \left(\mathrm{NO}_{3}^{-}\right)$results in the lowest $\mathrm{AIC}$ value. The AIC analysis suggests that adding further

254 information does not significantly improve this, although a higher $\mathrm{R}^{2}$ value is possible using more variables (See Table 5). Multivariate regression of the data grouped by the field proximity and date provides a better fit than that

256 of the individual measurements (Table 5 and Figure 5) accounting for $66 \%$ of the variance, although this is only increased slightly from the variance of $62 \%$ accounted for when using univariate linear regression with either $\mathrm{NO}_{3}{ }^{-}$or $\left.\log \left(\mathrm{NH}_{4}{ }^{+}\right)\right)$. Multivariate regression accounts for up to $91 \%$ of the variance in the data grouped by source type and season; however, this fit is heavily influenced by only 3 points with high associated available nitrogen and $\mathrm{N}_{2} \mathrm{O}$ flux measurements (i.e. manure contaminated soils) $\left(\mathrm{R}^{2}=0.76\right.$ without these points) (See Figure 5). 
262 Mean fluxes measured from the feature areas were considerably higher than those measured from the general field

263 areas, by about two or three orders of magnitude (Table 6). However, the general field areas contributed more to

264 the whole-farm emissions than the feature areas (Table 7), due to their large area occupying around $99.7 \%$ of the

265 farm. Seasonal differences were observed in fluxes from the general field areas, with the highest values observed

266 in spring and summer (Table 6). This same pattern was reflected in the farm-scale flux estimates (Table 7). In

267 the spring and summer, the general field areas contributed 77 to $93 \%$ of the whole-farm emission (depending on

268 statistical method, Table 7). In winter, fluxes from the general field areas were very low, and the feature areas

269 dominated the whole-farm-scale emission, contributing between 74 to $91 \%$ of the total (Table 7). values occurred in the sample, and were lower in data sets without large outliers. The naïve sample confidence

272 intervals are symmetrical, and the lower limit was often negative (and probably erroneous) and the upper limit

273 was often implausibly large. The Bayesian and or Zou et al., 2009 methods provided plausible, asymmetric

274 confidence intervals, which were often similar. When sample size was small or variability very large, the method

275 of Zou et al., 2009 produced very high upper limits, sometimes several orders of magnitude too high (Table 7),

276 and these have to be considered implausible, given the data. The Bayesian method was robust, giving plausible

277 confidence intervals in all cases, and is the preferred method, despite the slightly greater computation time and

278 complexity. Where a log-normal distribution is not well-defined by the data (such as for the feature areas), the

279 Bayesian method tends to estimate a lower mean than the method of Zou et al., 2009, which is a consequence of

280 the prior we used. 


\section{Discussion}

284 This study highlights the variability of $\mathrm{N}_{2} \mathrm{O}$ fluxes present at the farm scale and the difficulties involved in 285 upscaling these measurements. Individual flux measurements ranging from -5.5 to as large as $80,000 \mu \mathrm{g} \mathrm{N}_{2} \mathrm{O}-\mathrm{N}$ $286 \mathrm{~m}^{-2} \mathrm{~h}^{-1}$ were recorded from various sources present at the farm; however a large proportion of the measured fluxes 287 were close to zero. The detection limit of the dynamic chamber method used is estimated to be $4 \mu \mathrm{g} \mathrm{N}_{2} \mathrm{O}-\mathrm{N} \mathrm{m}^{-2}$ $288 \mathrm{~h}^{-1}$ (Cowan et al., 2014a). As $20 \%$ of the fluxes measured at the farm scale were lower than this detection limit, 289 it is likely that the large proportion (11\%) of negative fluxes recorded during the study are a result of the detection 290 limit of the instrumentation rather than the measurement of true negative fluxes (Cowan et al., 2014b). This 291 highlights the need for flux measurement methodology with low detection limits for detailed investigation of $\mathrm{N}_{2} \mathrm{O}$ 292 fluxes and relationships between emissions and the soil properties which drive microbial processes in agricultural 293 soils. The largest $\mathrm{N}_{2} \mathrm{O}$ fluxes per unit area observed were generally measured from the feeding areas, manurecontaminated areas, animal barns and manure heaps. These fluxes can be attributed to the higher concentration of available nitrogen from animal waste deposited to these areas. The farm-scale contribution to fluxes from these sources is difficult to estimate for two reasons. Firstly, difficulties remain in accurately identifying (or defining)

298 the area occupied by these features. In this study, stratification of the farm area was achieved using a mixture of 299 GPS measurements and some assumptions to estimate the areas of each of the feature areas. However, this method 300 grossly generalises these features which in reality, may be considerably different between different fields under different management. Each area of the farm would require numerous flux and soil measurements to properly

302 define it, which becomes impractical at increasingly large scales. It is also possible that further areas exist within 303 the grazing fields in which animal waste deposition (and therefore available nitrogen) is significantly higher than 304 the general field coverage such as ditches, riparian areas and shaded or dryer areas which are not accounted for in 305 this study (Cowan et al., 2015; Groffman et al., 2000; Matthews et al., 2010). The second difficulty is that spatial 306 variability from these sources is large, resulting in very large uncertainties when upscaling. The direct log 307 relationship between $\mathrm{N}_{2} \mathrm{O}$ flux and available nitrogen explains in part why these very large fluxes occur; however, 308 it does little to help improve up-scaling estimates as spatial variability in available nitrogen is just as unpredictable 309 as that of $\mathrm{N}_{2} \mathrm{O}$ and is also more expensive to measure. The results in this study suggest that although flux 310 contributions from these low area coverage high flux sources are smaller than the contribution from the general 
311 field areas, they are still significant enough to include in large scale (farm to regional) $\mathrm{N}_{2} \mathrm{O}$ inventories. It is also

312 worth considering that, as each farm is unique in terms of size and management, the contributions from these

313 sources are likely to vary considerably on a farm to farm basis.

314 Fluxes measured from the general areas on the fields in spring and summer were larger than those in 315 autumn and winter. It is likely that these seasonal variations are caused by multiple seasonal variations in soil 316 conditions rather than a single definitive factor, although the only statistically significant correlation observed 317 between the measurements in this study is the relationship between flux and available nitrogen (Figure 5).

318 Measurements were made at times chosen to avoid peaks in fluxes after fertilisation events which tend to occur 319 in a three week period after fertilisation (Skiba et al., 2013; Smith et al., 2012); however, the majority of nitrogen 320 fertilisers used at the farm were applied to the fields in spring and summer and it is likely the elevated available 321 nitrogen measured across the farm in these seasons is partly due to remaining residues of these fertilisers in soils. 322 Higher nitrogen in soils may also be due to animal waste input, especially in the densely stocked sheep fields 323 during the lambing season. It is known that elevated available nitrogen in soils from livestock waste results in 324 larger $\mathrm{N}_{2} \mathrm{O}$ fluxes (Gill et al., 2010; Šimek et al., 2006); however, a relationship is sometimes difficult to define 325 in field studies due to the competing effects of numerous other heterogeneous soil properties, especially WFPS, 326 which influence fluxes in a less discernible manner. Other studies have also observed seasonal variation in $\mathrm{N}_{2} \mathrm{O}$

327 fluxes from animal waste, but relationships between nitrogen deposition and fluxes reported in these publications 328 are inconsistent with our observations (Allen et al., 1996; Wolf et al., 2010).

\subsection{Spatial interpolation of $\mathrm{N}_{2} \mathrm{O}$ flux measurements}

330 Upscaling chamber fluxes spatially has proven difficult in many studies (Folorunso and Rolston, 1984; Hénault et al., 2012; Velthof et al., 1996). Variation in $\mathrm{N}_{2} \mathrm{O}$ flux measurements observed in this study was as similar at small distances $(<10 \mathrm{~m})$ as it was at large distances $(>100 \mathrm{~m})$ from all sources. This is a common phenomenon when measuring $\mathrm{N}_{2} \mathrm{O}$ with flux chambers (Ball et al., 1997; Hargreaves et al., 2015). Without a spatial pattern the

334 use of interpolation methods such as kriging and regression models are limited. In this study no statistically significant variance could be identified between flux measurements at any scale, although a consistent and randomly spaced log-normal distribution of measured flux magnitude was observed across all sources of $\mathrm{N}_{2} \mathrm{O}$ at the farm. The observation of log-normal distributions in $\mathrm{N}_{2} \mathrm{O}$ flux measurements is very common from agricultural soils (Folorunso and Rolston, 1984; Velthof et al., 1996; Yanai et al., 2003). 
340 sample mean can result in poor flux estimates because of its sensitivity to outliers. Zou's method generally gave 341 results similar to the Bayesian method, but in some cases the uncertainties were implausibly large, when sample

342 size was small and fluxes were high. The Bayesian method allows us to account for the log-normal distribution

343 of the data and propagate the associated uncertainty appropriately to the farm scale. In terms of systematic bias

344 between the methods, there were some differences that were consistent with theory. The naive sample mean is an

345 unbiased estimator in the statistical sense, meaning that with a large enough sample size, it will not deviate

346 systematically from the population mean. However, it is recognised that it is an inefficient estimator of the

347 population mean, meaning that it requires a large sample to be accurate. With small sample sizes and large

348 variance (as is normal with flux data), it will typically underestimate the population mean (because infrequent,

349 high values will often be missing from the sample). When high values are perchance included in the sample, it

350 will typically overestimate the population mean. Here, we explicitly attempt to incorporate high values in our

351 sampling, by focusing on hot spots and point sources, usually ignored in field surveys. Hence, the naive method

352 often produces overestimates in these data sets, compared to the other methods which account for the lognormal

353 distribution. We note that this is atypical, and that underestimation by the naive sample mean will be the more

354 common problem.

The use of methods which cover larger areas when measuring fluxes such as eddy covariance may provide better spatially and temporally integrated data sets for individual fields. Potentially, top-down approaches such as the use of tall towers to measure gas fluxes in the future may improve regional flux inventories without the need for multiple bottom up studies (Baldocchi, 2014; Zhang et al., 2014). or temporally is one potential way to up-scale fluxes to the farm scale (i.e. using the relationship between $\mathrm{N}_{2} \mathrm{O}$ flux and available nitrogen which explains much of the variability in the observations in this study), but many hurdles remain. Empirical relationships between $\mathrm{N}_{2} \mathrm{O}$ flux and soil properties have been reported in the past, each with unique values that best fit their particular data set and measurement conditions (Flechard et al., 2007; Schmidt et al., 2000). The spatial variability of available nitrogen in the soils at the field scale is also similar to that of $\mathrm{N}_{2} \mathrm{O}$ and a large amount of additional (and prohibitively expensive) soil nitrogen measurements would be required to improve flux estimates using any predicted relationship. 
368 than the maximum values reported in other studies which tend to range from 60 to $90 \%$ (Clayton et al., 1997;

369 Flechard et al., 2007; Schmidt et al., 2000). The relatively low value in WFPS in which fluxes peak in this study

370 is more likely to be an artefact of seasonal changes in available nitrogen in the soil than any effect that the WFPS

371 may have on fluxes. Due to the seasonal differences in available nitrogen in this study it is difficult to separate the

372 effects of environmental change on $\mathrm{N}_{2} \mathrm{O}$ and effects of the additional nitrogen present in the warmer and drier

373 periods of spring and summer.

374 
376 The most significant driver of $\mathrm{N}_{2} \mathrm{O}$ fluxes in this study was nitrogen in the form of $\mathrm{NH}_{4}{ }^{+}$and $\mathrm{NO}_{3}{ }^{-}$. Available

377 nitrogen in soils can be as spatially variable as $\mathrm{N}_{2} \mathrm{O}$ flux over small and large scales, and it is likely this

378 heterogeneous nature is a significant factor in the spatially unpredictable log-normal distribution of flux

379 measurements. The use of Bayesian methods can improve estimates of upscaled fluxes and their associated

380 uncertainties when the underlying data are log-normally distributed. $\mathrm{N}_{2} \mathrm{O}$ fluxes measured from features such as

381 animal feeding troughs, manure heaps and animal barns were typically one to four orders of magnitude higher

382 than those measured from the rest of the farm. However, these sources were typically found to contribute less $\mathrm{N}_{2} \mathrm{O}$

383 at the farm scale when compared to the extensive arable and pasture fields (which covered $99.7 \%$ of the area).

384 The small contribution from the features can sometimes be significant at the farm scale, as potentially up to $91 \%$

385 of the fluxes may come from only $0.3 \%$ of the area coverage in some cases, and large uncertainties persist in

386 these calculations.

\section{Acknowledgements}

We thank Scotland's Rural College and University of Edinburgh farms, especially Alex Moir and Wim Bosma for providing the field site and farm data. We also thank DEFRA and the UK Devolved Administrations for financial support through the UK GHG Platform project AC0116 (The InveN2Ory project).

\section{References}

Allen, A.G., Jarvis, S.C., Headon, D.M., 1996. Nitrous oxide emissions from soils due to inputs of nitrogen from excreta return by livestock on grazed grassland in the U.K. Soil Biol. Biochem. 28, 597-607. doi:10.1016/0038-0717(95)00186-7

Baggs, E.M., 2008. A review of stable isotope techniques for $\mathrm{N} 2 \mathrm{O}$ source partitioning in soils: recent progress, remaining challenges and future considerations. Rapid Commun. Mass Spectrom. 22, 1664-1672. doi: $10.1002 / \mathrm{rcm} .3456$

Baldocchi, D., 2014. Measuring fluxes of trace gases and energy between ecosystems and the atmosphere - the state and future of the eddy covariance method. Glob. Change Biol. 20, 3600-3609. doi: $10.1111 / \mathrm{gcb} .12649$

Ball, B.C., Horgan, G.W., Clayton, H., Parker, J.P., 1997. Spatial Variability of Nitrous Oxide Fluxes and Controlling Soil and Topographic Properties. J. Environ. Qual. 26. doi:10.2134/jeq1997.00472425002600050029x at different water-filled pore space. Biol. Fertil. Soils 41, 379-388. doi:10.1007/s00374-005-0858-3 
Brown, L., Jarvis, S.C., Headon, D., 2001. A farm-scale basis for predicting nitrous oxide emissions from dairy farms. Nutr. Cycl. Agroecosystems 60, 149-158. doi:10.1023/A:1012659801484

408

409

410

411

412

413

414

415

416

417

418

419

420

421

422

423

424

425

426

427

428

429

430

431

432

433

434

435

436

437

438

439

440

441

442

443

444

445

446

447

Burnham KP, Anderson DR, editors. Model Selection and Multimodel Inference [Internet]. New York, NY: Springer New York; 2004 [cited 2017 Mar 22]. Available from: http://link.springer.com/10.1007/b97636Butterbach-Bahl, K., Baggs, E.M., Dannenmann, M., Kiese, R., Zechmeister-Boltenstern, S., 2013. Nitrous oxide emissions from soils: how well do we understand the processes and their controls? Philos. Trans. R. Soc. B Biol. Sci. 368, 20130122-20130122. doi:10.1098/rstb.2013.0122

Chadwick, D.R., Sneath, R.W., Phillips, V.R., Pain, B.F., 1999. A UK inventory of nitrous oxide emissions from farmed livestock. Atmos. Environ. 33, 3345-3354. doi:10.1016/S1352-2310(98)00379-3

Clayton, H., McTaggart, I.P., Parker, J., Swan, L., Smith, K.A., 1997. Nitrous oxide emissions from fertilised grassland: A 2-year study of the effects of $\mathrm{N}$ fertiliser form and environmental conditions. Biol. Fertil. Soils 25, 252-260. doi:10.1007/s003740050311

Cowan, N.J., Famulari, D., Levy, P.E., Anderson, M., Bell, M.J., Rees, R.M., Reay, D.S., Skiba, U.M., 2014a. An improved method for measuring soil $\mathrm{N}_{2} \mathrm{O}$ fluxes using a quantum cascade laser with a dynamic chamber. Eur. J. Soil Sci. 65, 643-652. doi:10.1111/ejss.12168

Cowan, N.J., Famulari, D., Levy, P.E., Anderson, M., Reay, D.S., Skiba, U.M., 2014b. Investigating uptake of $\mathrm{N}_{2} \mathrm{O}$ in agricultural soils using a high-precision dynamic chamber method. Atmospheric Meas. Tech. 7, 4455-4462. doi:10.5194/amt-7-4455-2014

Cowan, N.J., Norman, P., Famulari, D., Levy, P.E., Reay, D.S., Skiba, U.M., 2015. Spatial variability and hotspots of soil $\mathrm{N}_{2} \mathrm{O}$ fluxes from intensively grazed grassland. Biogeosciences 12, 1585-1596. doi:10.5194/bg-12-1585-2015

Davidson, E.A., 1992. Sources of Nitric Oxide and Nitrous Oxide following Wetting of Dry Soil. Soil Sci. Soc. Am. J. 56, 95. doi:10.2136/sssaj1992.03615995005600010015x

Davidson, E.A., Keller, M., Erickson, H.E., Verchot, L.V., Veldkamp, E., 2000. Testing a Conceptual Model of Soil Emissions of Nitrous and Nitric Oxides: Using two functions based on soil nitrogen availability and soil water content, the hole-in-the-pipe model characterizes a large fraction of the observed variation of nitric oxide and nitrous oxide emissions from soils. BioScience 50, 667-680. doi:10.1641/0006-3568(2000)050[0667:TACMOS]2.0.CO;2

Ellis, S., Webb, J., Misselbrook, T., Chadwick, D., 2001. Emission of ammonia $\left(\mathrm{NH}_{3}\right)$, nitrous oxide $\left(\mathrm{N}_{2} \mathrm{O}\right)$ and methane $\left(\mathrm{CH}_{4}\right)$ from a dairy hardstanding in the UK. Nutr. Cycl. Agroecosystems 60, 115-122. doi:10.1023/A:1012608100518

El-Shaarawi, A.H., Lin, J., 2007. Interval estimation for log-normal mean with applications to water quality. Environmetrics 18, 1-10.

Flechard, C.R., Ambus, P., Skiba, U., Rees, R.M., Hensen, A., van Amstel, A., et al., 2007. Effects of climate and management intensity on nitrous oxide emissions in grassland systems across Europe. Agric. Ecosyst. Environ. 121, 135-152. doi:10.1016/j.agee.2006.12.024

Flessa, H., Ruser, R., Dörsch, P., Kamp, T., Jimenez, M.., Munch, J.,, Beese, F., 2002. Integrated evaluation of greenhouse gas emissions $\left(\mathrm{CO} 2, \mathrm{CH} 4, \mathrm{~N}_{2} \mathrm{O}\right)$ from two farming systems in southern Germany. Agric. Ecosyst. Environ. 91, 175-189. doi:10.1016/S0167-8809(01)00234-1

Folorunso, O.A., Rolston, D.E., 1984. Spatial Variability of Field-Measured Denitrification Gas Fluxes1. Soil Sci. Soc. Am. J. 48, 1214. doi:10.2136/sssaj1984.03615995004800060002x 
Fowler, D., Coyle, M., Skiba, U., Sutton, M.A., Cape, J.N., Reis, S., et al., 2013. The global nitrogen cycle in the twenty-first century. Philos. Trans. R. Soc. B Biol. Sci. 368, 20130164-20130164. doi:10.1098/rstb.2013.0164

Gill, M., Smith, P., Wilkinson, J.M., 2010. Mitigating climate change: the role of domestic livestock. animal 4, 323. doi:10.1017/S1751731109004662

Giltrap, D.L., Berben, P., Palmada, T., Saggar, S., 2014. Understanding and analysing spatial variability of nitrous oxide emissions from a grazed pasture. Agric. Ecosyst. Environ. 186, 1-10. doi:10.1016/j.agee.2014.01.012

Groffman, P.M., Gold, A.J., Addy, K., 2000. Nitrous oxide production in riparian zones and its importance to national emission inventories. Chemosphere - Glob. Change Sci. 2, 291-299. doi:10.1016/S14659972(00)00018-0

Hargreaves, P.R., Rees, R.M., Horgan, G.W., Ball, B.C., 2015. Size and Persistence of Nitrous Oxide Hot-Spots in Grazed and Ungrazed Grassland. Environ. Nat. Resour. Res. 5, 1. doi:10.5539/enrr.v5n4p1

Hénault, C., Grossel, A., Mary, B., Roussel, M., LéOnard, J., 2012. Nitrous Oxide Emission by Agricultural Soils: A Review of Spatial and Temporal Variability for Mitigation. Pedosphere 22, 426-433. doi:10.1016/S1002-0160(12)60029-0

Intergovernmental Panel on Climate Change (Ed.), 2014. Climate Change 2013 - The Physical Science Basis: Working Group I Contribution to the Fifth Assessment Report of the Intergovernmental Panel on Climate Change. Cambridge University Press, Cambridge.

Kim, D.-G., Hernandez-Ramirez, G., Giltrap, D., 2013. Linear and nonlinear dependency of direct nitrous oxide emissions on fertilizer nitrogen input: A meta-analysis. Agric. Ecosyst. Environ. 168, 53-65. doi:10.1016/j.agee.2012.02.021

Land, C.E., 1972. An evaluation of approximate confidence interval estimation methods for lognormal means. Technometrics 14, 145-158.

Lumley, T. 2015. Leaps Package, Regression subset selection. URL https://cran.rproject.org/web/packages/leaps/leaps.pdf

Ma, B.L., Wu, T.Y., Tremblay, N., Deen, W., Morrison, M.J., Mclaughlin, N.B., Gregorich, E.G., Stewart, G., 2010. Nitrous oxide fluxes from corn fields: on-farm assessment of the amount and timing of nitrogen fertilizer: nitrogen fertilizer impact on $\mathrm{N}_{2} \mathrm{O}$ emission. Glob. Change Biol. 16, 156-170. doi:10.1111/j.1365-2486.2009.01932.x

Mathieu, O., Leveque, J., Henault, C., Milloux, M., Bizouard, F., Andreux, F., 2006. Emissions and spatial variability of $\mathrm{N}_{2} \mathrm{O}, \mathrm{N}_{2}$ and nitrous oxide mole fraction at the field scale, revealed with $15 \mathrm{~N}$ isotopic techniques. Soil Biol. Biochem. 38, 941-951. doi:10.1016/j.soilbio.2005.08.010

Matthews, R.A., Chadwick, D.R., Retter, A.L., Blackwell, M.S.A., Yamulki, S., 2010. Nitrous oxide emissions from small-scale farmland features of UK livestock farming systems. Agric. Ecosyst. Environ. 136, 192-198. doi:10.1016/j.agee.2009.11.011

Millard, S.P., 2013. EnvStats: an R package for environmental statistics. Springer, New York.

Parkin, T., Chester, S., Robinson, J., 1990. Calculating confidence intervals for the mean of a lognormally distributed variable. Soil Sci. Soc. Am. J. 54, 321-326.

Plummer M., 2003. JAGS: A program for analysis of Bayesian graphical models using Gibbs sampling. URL http://citeseer.ist.psu.edu/plummer03jags.html. 
R Core Team (2013). R: A language and environment for statistical computing. R Foundation for Statistical Computing, Vienna, Austria. ISBN 3-900051-07-0, URL http://www.R-project.org/.

Ravishankara, A.R., Daniel, J.S., Portmann, R.W., 2009. Nitrous Oxide $\left(\mathrm{N}_{2} \mathrm{O}\right)$ : The Dominant Ozone-Depleting Substance Emitted in the 21st Century. Science 326, 123-125. doi:10.1126/science.1176985

493

Reay, D.S., Davidson, E.A., Smith, K.A., Smith, P., Melillo, J.M., Dentener, F., Crutzen, P.J., 2012. Global agriculture and nitrous oxide emissions. Nat. Clim. Change 2, 410-416. doi:10.1038/nclimate1458

Reay, D.S., Edwards, A.C., Smith, K.A., 2009. Importance of indirect nitrous oxide emissions at the field, farm and catchment scale. Agric. Ecosyst. Environ. 133, 163-169. doi:10.1016/j.agee.2009.04.019

Ribeiro P.J., Diggle P.J., 2016. geoR: Analysis of Geostatistical Data. R package version 1.7-5.2. https://CRAN.R-project.org/package $=$ geoR

Rowell, D.L., 1994. Soil science: methods and applications. Longman Scientific \& Technical; Wiley, Harlow, Essex : New York.

Schmidt, U., Thöni, H., Kaupenjohann, M., 2000. Using a boundary line approach to analyze $\mathrm{N}_{2} \mathrm{O}$ flux data from agricultural soils. Nutr. Cycl. Agroecosystems 57, 119-129. doi:10.1023/A:1009854220769

Shcherbak, I., Millar, N., Robertson, G.P., 2014. Global metaanalysis of the nonlinear response of soil nitrous oxide $\left(\mathrm{N}_{2} \mathrm{O}\right)$ emissions to fertilizer nitrogen. Proc. Natl. Acad. Sci. 111, 9199-9204. doi:10.1073/pnas.1322434111

Šimek, M., Brůček, P., Hynšt, J., Uhlířová, E., Petersen, S.O., 2006. Effects of excretal returns and soil compaction on nitrous oxide emissions from a cattle overwintering area. Agric. Ecosyst. Environ. 112, 186-191. doi:10.1016/j.agee.2005.08.018

Skiba, U., Jones, S.K., Drewer, J., Helfter, C., Anderson, M., Dinsmore, K., McKenzie, R., Nemitz, E., Sutton, M.A., 2013. Comparison of soil greenhouse gas fluxes from extensive and intensive grazing in a temperate maritime climate. Biogeosciences 10, 1231-1241. doi:10.5194/bg-10-1231-2013

Smith, K., Dobbie, K., Thorman, R., Watson, C., Chadwick, D., Yamulki, S., Ball, B., 2012. The effect of N fertilizer forms on nitrous oxide emissions from UK arable land and grassland. Nutr. Cycl. Agroecosystems 93, 127-149. doi:10.1007/s10705-012-9505-1

Thomson, A.J., Giannopoulos, G., Pretty, J., Baggs, E.M., Richardson, D.J., 2012. Biological sources and sinks of nitrous oxide and strategies to mitigate emissions. Philos. Trans. R. Soc. B Biol. Sci. 367, $1157-$ 1168. doi:10.1098/rstb.2011.0415

Thornton, P.K., 2010. Livestock production: recent trends, future prospects. Philos. Trans. R. Soc. Lond. B Biol. Sci. 365, 2853-2867. doi:10.1098/rstb.2010.0134

Velthof, G., Oenema, O., 1997. Nitrous oxide emission from dairy farming systems in the Netherlands. NJAS Wagening. J. Life Sci. 45, 347-360.

Velthof, G.L., Jarvis, S.C., Stein, A., Allen, A.G., Oenema, O., 1996. Spatial variability of nitrous oxide fluxes in mown and grazed grasslands on a poorly drained clay soil. Soil Biol. Biochem. 28, 1215-1225. doi:10.1016/0038-0717(96)00129-0

Wild, P., Hordan, R., Leplay, A., Vincent, R., 1996. Confidence intervals for probabilities of exceeding threshold limits with censored log-normal data. Environmetrics 7, 247-259.

Wolf, B., Zheng, X., Brüggemann, N., Chen, W., Dannenmann, M., Han, X., Sutton, M.A., Wu, H., Yao, Z., Butterbach-Bahl, K., 2010. Grazing-induced reduction of natural nitrous oxide release from continental 
steppe. Nature 464, 881-884. Yanai, J., Sawamoto, T., Oe, T., Kusa, K., Yamakawa, K., Sakamoto, K., Naganawa, T., Inubushi, K., Hatano, R., Kosaki, T., 2003. Spatial Variability of Nitrous Oxide

Emissions and Their Soil-Related Determining Factors in an Agricultural Field. J. Environ. Qual. 32, 1965. doi:10.2134/jeq2003.1965

Zellner, A., 1971. Bayesian and non-Bayesian analysis of the log-normal distribution and log-normal regression. J. Am. Stat. Assoc. 66, 327-330.

Zhang, X., Lee, X., Griffis, T.J., Baker, J.M., Xiao, W., 2014. Estimating greenhouse gas fluxes from an agriculture-dominated landscape using multiple planetary boundary layer methods. Atmospheric Chem. Phys. Discuss. 14, 3231-3267. doi:10.5194/acpd-14-3231-2014

Zou, G., Huo, C.Y., Taleban, J., 2009. Simple confidence intervals for lognormal means and their differences with environmental applications. Environmetrics 20, 172-180. 

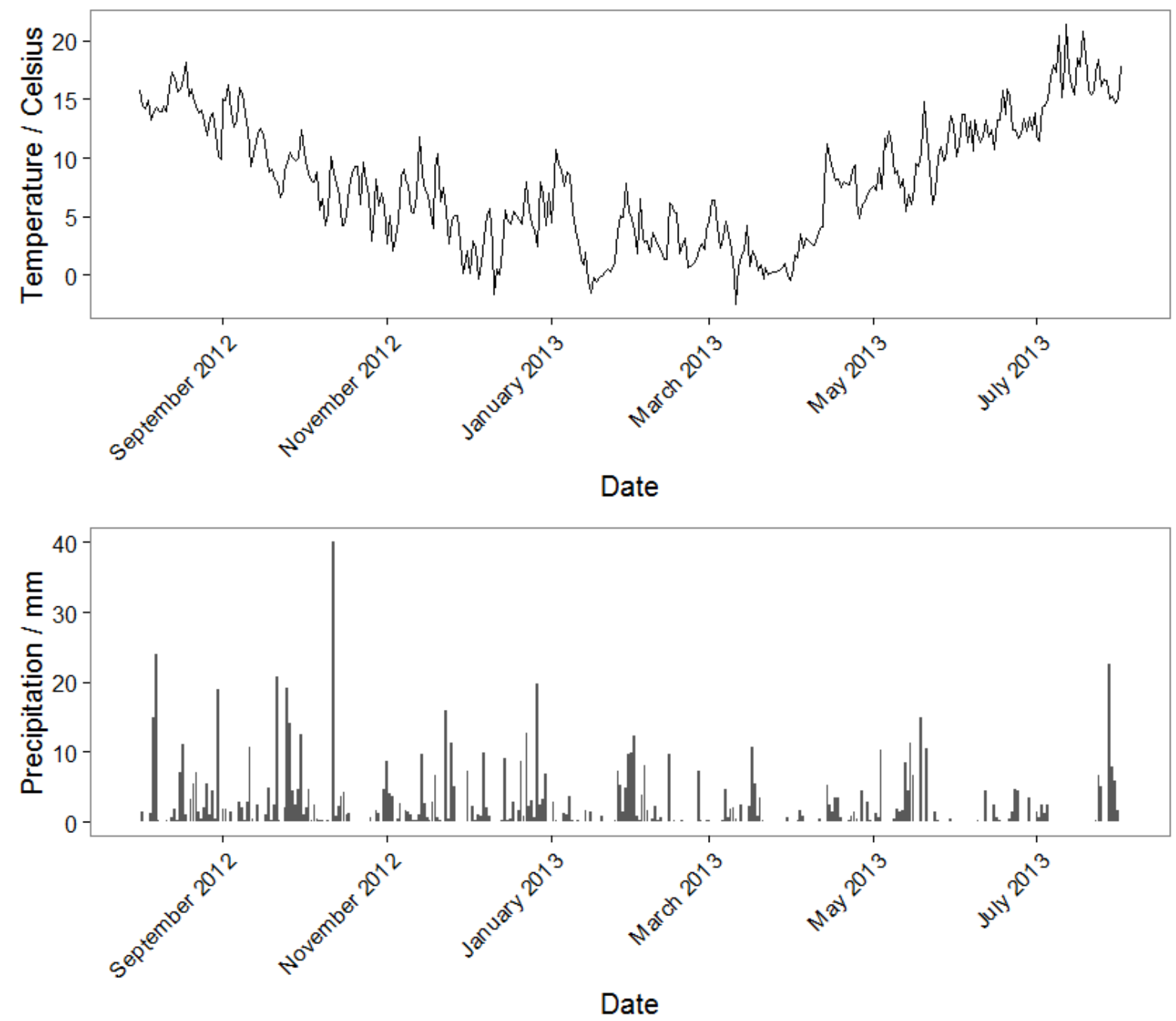

542 Figure 1 (a) Cumulative annual rainfall and (b) daily average temperature were plotted for the years $2001-2013$

543 (each line representing a different year) at the Easter Bush Farm Estate. The measurement period of the study is 544 represented with a solid black line in both figures (Jan - Aug 2013 and Sep - Dec 2012). 


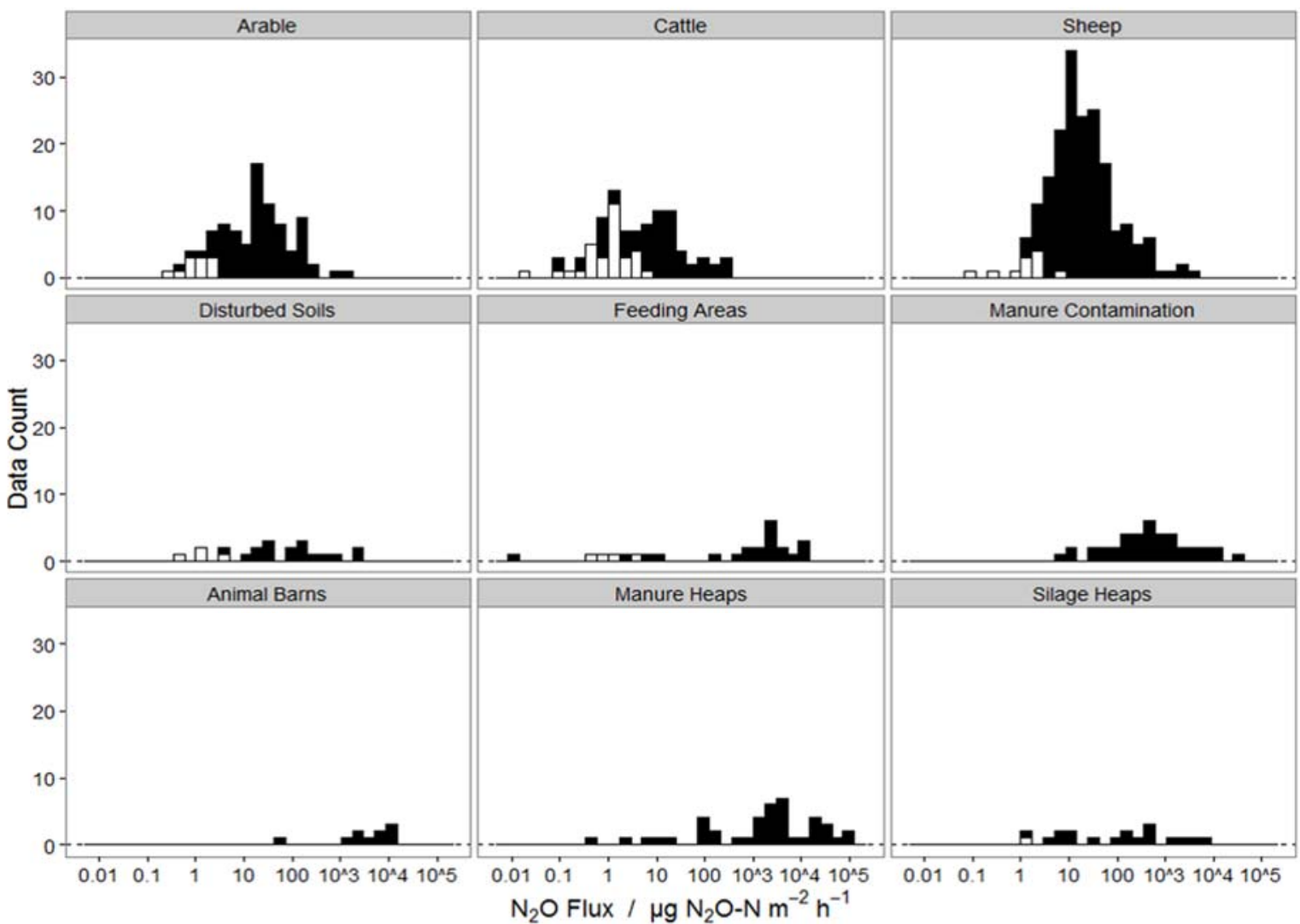

546 Figure 2 Frequency distribution of observed $\mathrm{N}_{2} \mathrm{O}$ fluxes from the different sources at the farm, shown on a $\log$ 547 transformed axis. Measurements representing areas of general field coverage are separated based on management 548 (top). Six sources of features are separated. Negative fluxes are shown on the positive scale but coloured white. 

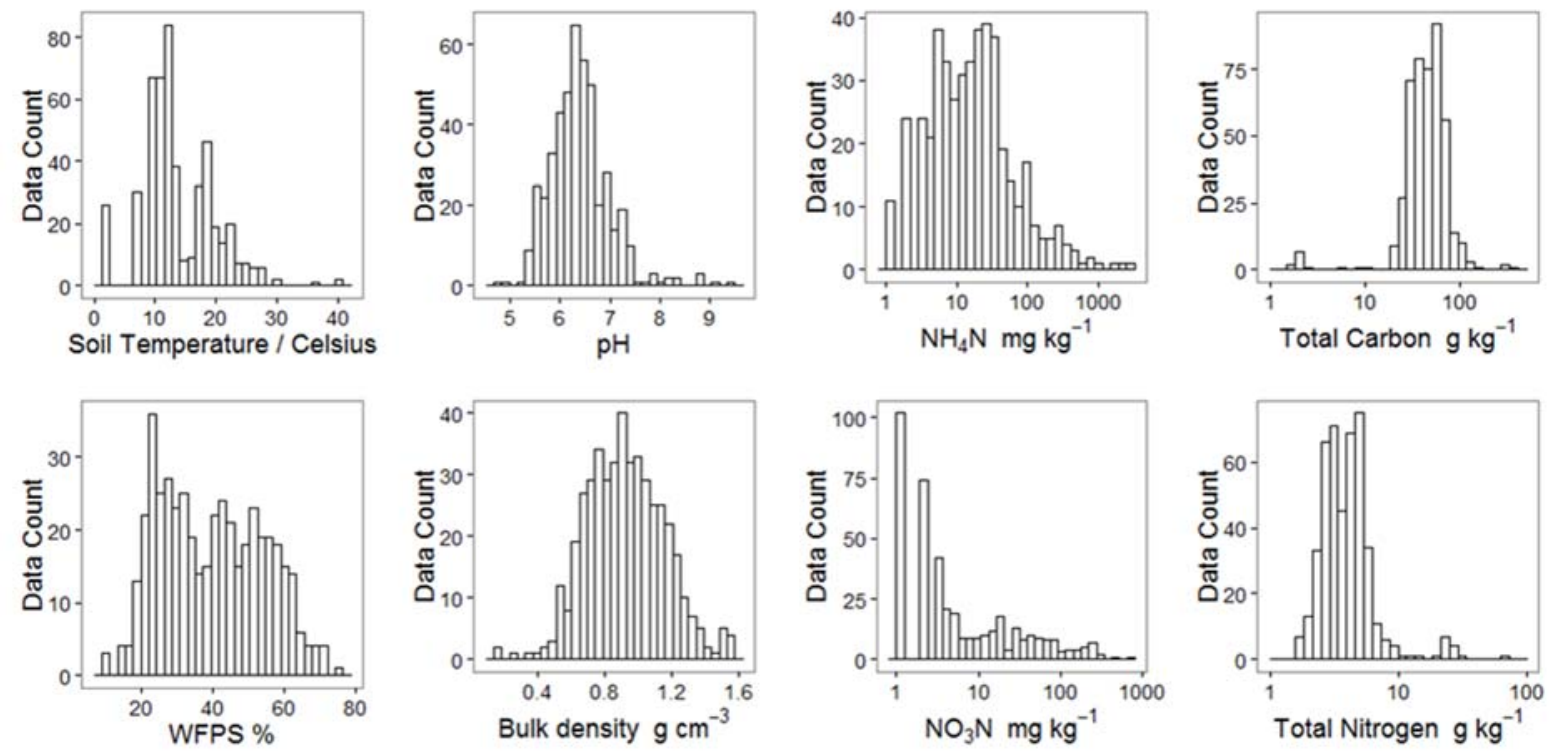

551 Figure 3 Frequency distribution of all soil measurements made on the farm. The physical properties

552 (temperature, WFPS and bulk density) of the soil followed a normal distribution, while the nitrogen and carbon content measurements are better described as a log-normal distribution. 


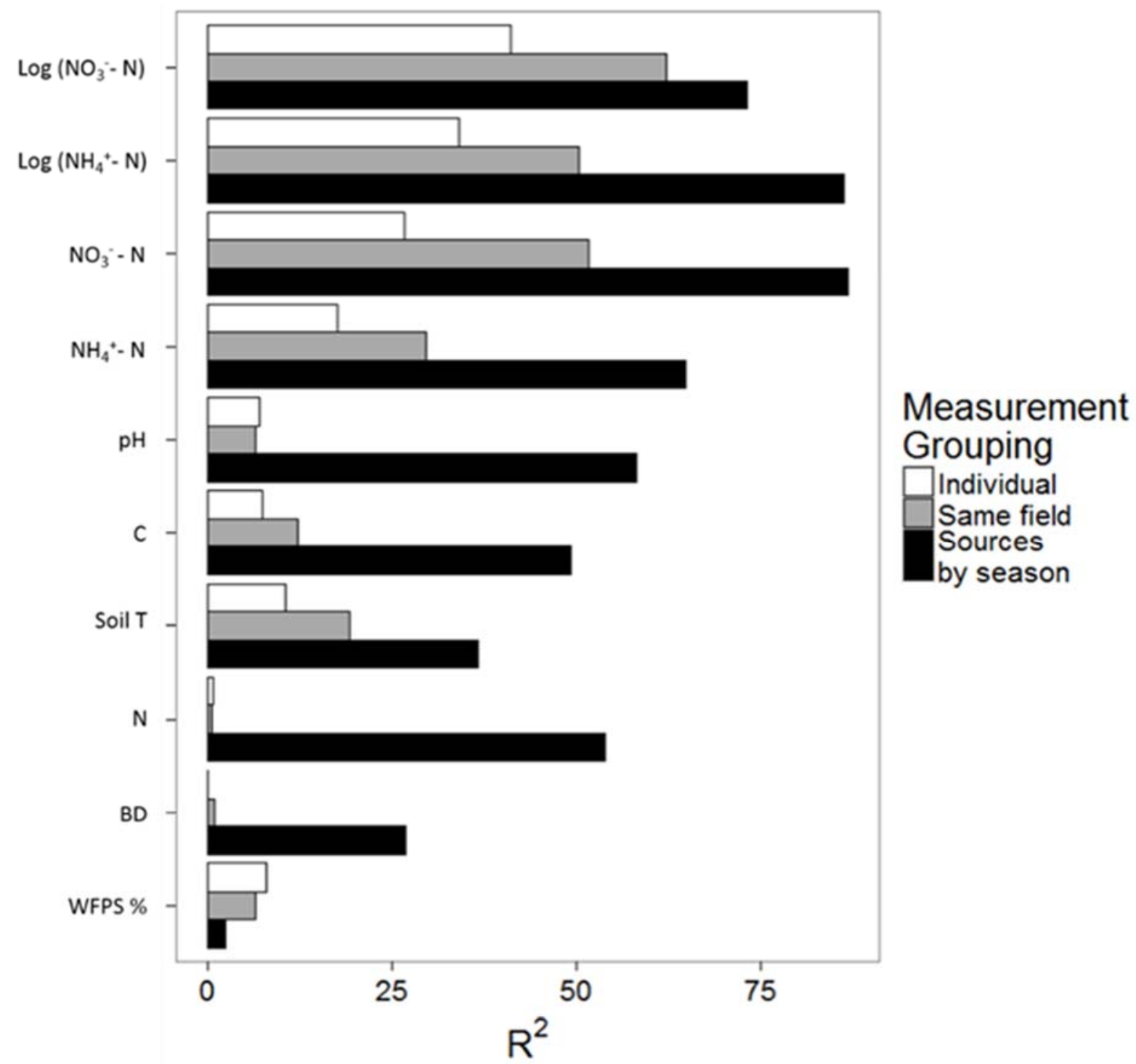

555

556 Figure 4 Percentage of variance in $\log \left(\mathrm{N}_{2} \mathrm{O}\right.$ flux $)$ explained by univariate linear regression with soil properties 557 (see Table 4 for units). 

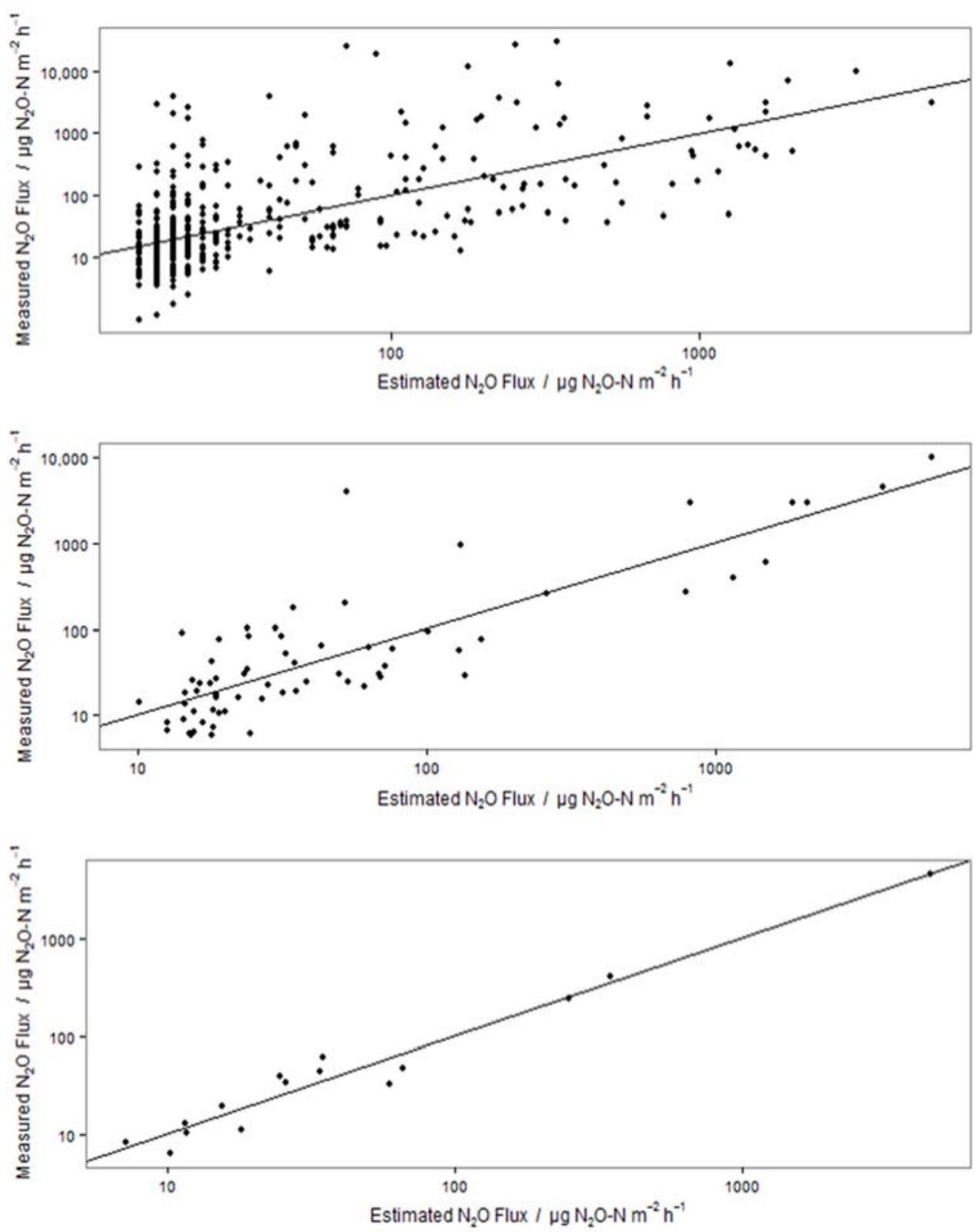

560 Figure 5 Measured $\mathrm{N}_{2} \mathrm{O}$ flux is plotted against fitted flux based on the best sub-sets regression model with the

561 lowest AIC value (See Table 5). The model fit between $\mathrm{N}_{2} \mathrm{O}$ flux and soil properties for (I) individual

562 measurements, (II) measurements made from the same field and date and (III) measurements made from the same source type and season. A 1:1 line is added to each plot. 
565 Table 1 A description of seasonal management of the each of the fields selected to represent the livestock farm

566 in this study.

\begin{tabular}{lccccc}
\hline Field Name & $\begin{array}{c}\text { Area } \\
\text { (ha) }\end{array}$ & $\begin{array}{c}\text { Autumn } \\
2012\end{array}$ & $\begin{array}{c}\text { Winter } \\
2012 / 2013\end{array}$ & $\begin{array}{c}\text { Spring } \\
2013\end{array}$ & $\begin{array}{c}\text { Summer } \\
2013\end{array}$ \\
\hline Corner Field & 6.72 & Sheep & Sheep & Sheep & Sheep \\
Engineers Field & 5.30 & Sheep & Sheep & Sheep & Sheep \\
Middle Field & 5.44 & Cattle & Sheep & Sheep & Sheep \\
Paddock Field & 4.08 & Sheep & Sheep & Sheep & Sheep \\
Bog Hall Field & 7.55 & Barley & Empty & Barley & Barley \\
Kimming Hill & 12.16 & Silage & Sheep & Silage & Silage \\
Anchordales & 2.67 & Barley & Empty & Barley & Barley \\
Anchordales N.L.T & 5.36 & Barley & Empty & Barley & Barley \\
Cow Loan & 4.79 & Barley & Empty & Barley & Barley \\
Hay Knowes & 10.92 & Barley & Oilseed & Oilseed & Barley \\
Crofts & 8.67 & Barley & Empty & Barley & Barley \\
Low Fulford & 7.72 & Silage & Sheep & Silage & Silage \\
Fulford Camp & 5.37 & Sheep & Sheep & Sheep & Sheep \\
Mid Fulford & 9.57 & Cattle & Empty & Sheep & Sheep \\
Fulford Stackyard & 3.68 & Sheep & Sheep & Sheep & Sheep \\
Upper Fulford & 4.48 & Sheep & Empty & Cattle & Cattle \\
Nuek & 4.89 & Cattle & Empty & Cattle & Cattle \\
Doo Brae & 5.76 & Sheep & Sheep & Cattle & Cattle \\
Woodhouselee Camp & 4.94 & Cattle & Cattle & Cattle & Cattle \\
Lower Terrace & 12.56 & Barley & Empty & Empty & Sheep \\
\hline
\end{tabular}


569 Table 2 Estimated area of each of the identified source categories. Areas change seasonally due to alternating $570 \quad$ use of fields (see Table 1)

\begin{tabular}{|c|c|c|c|c|c|c|c|c|}
\hline Source Category & $\begin{array}{r}\text { Autumn } \\
2012 \\
\end{array}$ & & $\begin{array}{r}\text { Winter } \\
2012 / 2013 \\
\end{array}$ & & $\begin{array}{r}\text { Spring } \\
2013 \\
\end{array}$ & & $\begin{array}{r}\text { Summer } \\
2013 \\
\end{array}$ & \\
\hline \multicolumn{9}{|l|}{ General fields (ha) } \\
\hline Arable & 60.2 & \pm 6.0 & 52.5 & \pm 5.3 & 77.8 & \pm 7.8 & 65.2 & \pm 6.5 \\
\hline Cattle & 24.8 & \pm 2.5 & 14.3 & \pm 1.4 & 20.1 & \pm 2.0 & 20.1 & \pm 2.0 \\
\hline Sheep & 47.6 & \pm 4.8 & 65.8 & \pm 6.6 & 34.8 & \pm 3.5 & 47.4 & \pm 4.7 \\
\hline \multicolumn{9}{|l|}{ Features $\left(\mathrm{m}^{2}\right)$} \\
\hline Feeding Areas & 520 & \pm 260 & 420 & \pm 210 & 520 & \pm 260 & 560 & \pm 280 \\
\hline Disturbed Soils & 1061 & \pm 503 & 1061 & \pm 503 & 1061 & \pm 503 & 1061 & \pm 503 \\
\hline Manure Contamination & 502 & \pm 251 & 322 & \pm 161 & 182 & \pm 91 & 122 & \pm 61 \\
\hline Manure Heaps & 30 & \pm 15 & 210 & \pm 105 & 350 & \pm 175 & 410 & \pm 205 \\
\hline Animal Barns & 1500 & \pm 750 & 2000 & \pm 1000 & 500 & \pm 250 & 500 & \pm 250 \\
\hline Silage Heaps & 280 & \pm 140 & 160 & \pm 80 & 80 & \pm 40 & 40 & \pm 20 \\
\hline
\end{tabular}

571

572 
573 Table 3 Number of $\mathrm{N}_{2} \mathrm{O}$ flux measurements made from each source category during the study period

\begin{tabular}{lccccc}
\hline Source Category & All & $\begin{array}{c}\text { Autumn } \\
2012^{\mathrm{a}}\end{array}$ & $\begin{array}{c}\text { Winter } \\
2012 / 2013^{\mathrm{b}}\end{array}$ & $\begin{array}{c}\text { Spring } \\
2013^{\mathrm{c}}\end{array}$ & $\begin{array}{c}\text { Summer } \\
2013^{\mathrm{d}}\end{array}$ \\
\hline General field areas & & & & & \\
Arable & 97 & 19 & 18 & 24 & 36 \\
Grassland - cattle-grazed & 92 & 23 & 29 & 29 & 11 \\
Grassland - sheep-grazed & 192 & 26 & 0 & 54 & 112 \\
& & & & & \\
Features & & & & & \\
Disturbed Soils & 15 & 6 & 6 & 0 & 3 \\
Grassland - feeding areas & 21 & 6 & 1 & 0 & 14 \\
Grassland - manure contaminated & 40 & 0 & 2 & 20 & 18 \\
Animal Barn & 10 & 0 & 0 & 0 & 10 \\
Manure Heaps & 42 & 11 & 5 & 6 & 20 \\
Silage Heaps & 20 & 0 & 0 & 10 & 10 \\
\hline
\end{tabular}

574

${ }^{\mathrm{a}} 24 / 09 / 12$ - 28/09/12, ${ }^{\mathrm{b}} 12 / 02 / 2013-14 / 02 / 2013,{ }^{\mathrm{c}}$ 03/05/2013 - 16/05/2013, ${ }^{\mathrm{d}} 02 / 07 / 2013-10 / 07 / 2013$ 
576 Table 4 Averaged values for each of the measured soil properties in the different source categories each season.

\begin{tabular}{|c|c|c|c|c|c|c|c|c|c|}
\hline $\begin{array}{l}\text { Source } \\
\text { categories }\end{array}$ & Season & $\begin{array}{r}\text { Soil T } \\
\left({ }^{\circ} \mathrm{C}\right)\end{array}$ & $\begin{array}{c}\text { WFPS } \\
(\%)\end{array}$ & $\mathrm{pH}$ & $\begin{array}{c}\text { Bulk Density } \\
\left(\mathrm{g} \mathrm{cm}^{-3}\right)\end{array}$ & $\begin{array}{l}\mathrm{NH}_{4}-\mathrm{N} \\
\left(\mathrm{mg} \mathrm{kg}^{-1}\right)\end{array}$ & $\begin{array}{l}\mathrm{NO}_{3}-\mathrm{N} \\
\left(\mathrm{mg} \mathrm{kg}^{-1}\right)\end{array}$ & $\begin{array}{c}\text { Total Carbon } \\
\quad\left(\mathrm{g} \mathrm{kg}^{-1}\right)\end{array}$ & $\begin{array}{c}\text { Total Nitrogen } \\
\qquad\left(\mathrm{g} \mathrm{kg}^{-1}\right)\end{array}$ \\
\hline Arable & Autumn & 12.3 & 60 & 6.4 & 1.3 & 3.0 & 1.2 & 42 & 3.0 \\
\hline Arable & Winter & 2.0 & 49 & 6.3 & 1.1 & 3.7 & 3.6 & 30 & 2.5 \\
\hline Arable & Spring & 12.1 & 29 & 6.5 & 1.0 & 23.6 & 22.0 & 34 & 2.9 \\
\hline Arable & Summer & 17.6 & 26 & 6.7 & 1.1 & 23.8 & 18.6 & 24 & 8.5 \\
\hline Cattle & Autumn & 10.6 & 49 & 6.4 & 0.9 & 14.8 & 2.0 & 53 & 4.2 \\
\hline Cattle & Winter & 7.0 & 52 & 6.5 & 0.9 & 8.6 & 1.6 & 52 & 4.2 \\
\hline Cattle & Spring & 10.3 & 47 & 6.1 & 0.8 & 23.7 & 5.4 & 57 & 4.7 \\
\hline Cattle & Summer & 18.3 & 26 & 6.3 & 0.8 & 15.6 & 2.0 & 62 & 4.6 \\
\hline Sheep & Autumn & 11.0 & 55 & 6.2 & 1.0 & 12.3 & 1.3 & 34 & 3.3 \\
\hline Sheep & Winter & NA & NA & NA & NA & NA & NA & NA & NA \\
\hline Sheep & Spring & 10.6 & 47 & 6.3 & 0.9 & 20.9 & 4.8 & 47 & 4.1 \\
\hline Sheep & Summer & 18.8 & 27 & 6.1 & 0.8 & 51.9 & 24.1 & 57 & 4.6 \\
\hline Feeding Areas & All* & 17.0 & 44 & 6.5 & 1.0 & 166.5 & 77.5 & 58 & 4.6 \\
\hline Disturbed Soils & All* & 9.3 & 43 & 6.4 & 1.0 & 21.0 & 11.7 & 36 & 6.7 \\
\hline Manure Cont. & All* & 12.8 & 36 & 6.8 & 1.0 & 117.8 & 90.4 & 47 & 3.9 \\
\hline
\end{tabular}

577 * All measurements for the yearlong study are combined into one group

578

579 
580 Table 5 Results of best sub-sets regression on $\log \left(\mathrm{N}_{2} \mathrm{O}\right.$ flux), which identifies the best combination of variables

581 for each grouping of data in the data sets. Models with the lowest AIC value are considered most suitable by the 582 analysis.

\begin{tabular}{|c|c|c|}
\hline Terms & Adjusted $\mathrm{R}^{2}$ & $\mathrm{AIC}$ \\
\hline \multicolumn{3}{|l|}{ Individual Measurements, $\mathrm{n}=449$} \\
\hline $\log \mathrm{NO}_{3}-\mathrm{N}$ & 0.41 & 210 \\
\hline $\log \mathrm{NO}_{3}-\mathrm{N}+\log \mathrm{NH}_{4}-\mathrm{N}+\mathrm{NO}_{3}-\mathrm{N}+\mathrm{NH}_{4}-\mathrm{N}+\mathrm{pH}+$ Soil $\mathrm{C}+$ Soil $\mathrm{T}+$ Bulk Dens & 0.49 & 240 \\
\hline $\log \mathrm{NO}_{3}-\mathrm{N}+\log \mathrm{NH}_{4}-\mathrm{N}+\mathrm{NH}_{4}-\mathrm{N}+\mathrm{pH}+$ Soil $\mathrm{C}+$ Soil $\mathrm{N}+$ Bulk Dens + WFPS $\%$ & 0.48 & 240 \\
\hline $\log \mathrm{NO}_{3}-\mathrm{N}+\log \mathrm{NH}_{4}-\mathrm{N}+\mathrm{NH}_{4}-\mathrm{N}+\mathrm{pH}+$ Soil $\mathrm{C}+$ Soil N + WFPS \% & 0.48 & 250 \\
\hline \multicolumn{3}{|l|}{ Grouped by field proximity, $n=71$} \\
\hline $\log \mathrm{NO}_{3}-\mathrm{N}+\log \mathrm{NH}_{4}-\mathrm{N}+\mathrm{NO}_{3}-\mathrm{N}+\mathrm{NH}_{4}-\mathrm{N}+\mathrm{pH}+$ Soil $\mathrm{C}+$ Soil $\mathrm{N}+$ Bulk Dens & 0.66 & -44 \\
\hline $\log \mathrm{NO}_{3}-\mathrm{N}+\log \mathrm{NH}_{4}-\mathrm{N}+\mathrm{NO}_{3}-\mathrm{N}+\mathrm{NH}_{4}-\mathrm{N}+\mathrm{pH}+$ Soil $\mathrm{N}+$ Bulk Dens & 0.66 & -48 \\
\hline $\log \mathrm{NO}_{3}-\mathrm{N}+\log \mathrm{NH}_{4}-\mathrm{N}+\mathrm{NO}_{3}-\mathrm{N}+\mathrm{NH}_{4}-\mathrm{N}+\mathrm{pH}+$ Soil N & 0.67 & -52 \\
\hline $\log \mathrm{NO}_{3}-\mathrm{N}+\log \mathrm{NH}_{4}-\mathrm{N}+\mathrm{NO}_{3}-\mathrm{N}+\mathrm{NH}_{4}-\mathrm{N}+$ Soil $\mathrm{N}$ & 0.67 & -56 \\
\hline \multicolumn{3}{|l|}{ Sources by season, $\mathbf{n}=15$} \\
\hline Log $\mathrm{NH}_{4}-\mathrm{N}+\mathrm{NO}_{3}-\mathrm{N}+\mathrm{pH}+$ Soil $\mathrm{C}+$ Soil $\mathrm{N}+$ Soil $\mathrm{T}+$ Bulk Dens + WFPS $\%$ & 0.9 & -23 \\
\hline Log $\mathrm{NH}_{4}-\mathrm{N}+\mathrm{NO}_{3}-\mathrm{N}+\mathrm{pH}+$ Soil $\mathrm{C}+$ Soil $\mathrm{N}+$ Soil T + WFPS $\%$ & 0.91 & -26 \\
\hline $\mathrm{NO}_{3}-\mathrm{N}$ & 0.87 & -26 \\
\hline $\log \mathrm{NO}_{3}-\mathrm{N}+\log \mathrm{NH}_{4}-\mathrm{N}+\mathrm{NO}_{3}-\mathrm{N}+$ Soil $\mathrm{C}+$ Soil N & 0.91 & -27 \\
\hline
\end{tabular}

583

584 
Table 6 Mean $\mathrm{N}_{2} \mathrm{O}$ flux values with 95 \% C.I.'s estimated for each source category per season using three different

586 methods of calculation (units in $\mu \mathrm{g} \mathrm{N}_{2} \mathrm{O}-\mathrm{N} \mathrm{m}^{-2} \mathrm{~h}^{-1}$ ).

\begin{tabular}{|c|c|c|c|c|c|c|c|c|c|c|c|}
\hline $\begin{array}{l}\text { Source } \\
\text { categories }\end{array}$ & Season & $\mathrm{n}$ & $\begin{array}{l}\text { Naive } \\
\text { Method } \\
\text { Mean Flux }\end{array}$ & $\begin{array}{l}95 \% \\
\text { C.I. } \\
\text { Lower }\end{array}$ & Upper & $\begin{array}{l}\text { Bayesian } \\
\text { Method } \\
\text { Mean Flux }\end{array}$ & 95 \% C.I. & Upper & $\begin{array}{l}\text { Zou's } \\
\text { Method } \\
\text { Mean } \\
\text { Flux } \\
\end{array}$ & $\begin{array}{l}95 \% \\
\text { C.I. } \\
\text { Lower }\end{array}$ & Upper \\
\hline \multirow[t]{4}{*}{ Arable } & Autumn & 19 & 6 & -25 & 36 & 3 & 0 & 6 & 4 & 1 & 18 \\
\hline & Winter & 18 & 6 & -7 & 19 & 7 & 4 & 13 & 6 & 3 & 10 \\
\hline & Spring & 24 & 64 & -75 & 203 & 65 & 41 & 101 & 63 & 41 & 119 \\
\hline & Summer & 36 & 102 & -326 & 530 & 81 & 51 & 128 & 81 & 52 & 159 \\
\hline \multirow[t]{4}{*}{ Cattle } & Autumn & 23 & 99 & -757 & 954 & 11 & 4 & 21 & 23 & 8 & 135 \\
\hline & Winter & 29 & $\mathbf{0}$ & -4 & 4 & $\mathbf{0}$ & -1 & 1 & $\mathbf{0}$ & -1 & 1 \\
\hline & Spring & 29 & 57 & -104 & 217 & 46 & 29 & 72 & 56 & 32 & 132 \\
\hline & Summer & 11 & 14 & 0 & 28 & 14 & 10 & 19 & 14 & 10 & 21 \\
\hline \multirow[t]{4}{*}{ Sheep } & Autumn & 26 & 46 & -273 & 365 & 21 & 9 & 42 & 27 & 11 & 128 \\
\hline & Winter & 0 & NA & NA & NA & NA & NA & NA & NA & NA & NA \\
\hline & Spring & 54 & 160 & -770 & 1090 & 60 & 43 & 83 & 99 & 60 & 208 \\
\hline & Summer & 112 & 111 & -752 & 973 & 55 & 41 & 73 & 58 & 42 & 87 \\
\hline Feeding Areas & All* & 15 & 2539 & -5125 & 10204 & 2865 & 764 & 8329 & 13094 & 2703 & $1.810^{7}$ \\
\hline Disturbed Soils & All* & 21 & 311 & -990 & 1611 & 212 & 91 & 456 & 319 & 122 & 3773 \\
\hline Manure Cont. & All* & 40 & 1749 & -7731 & 11230 & 1288 & 677 & 2339 & 1499 & 758 & 5585 \\
\hline Manure Heap & All* & 10 & 10828 & -28069 & 49726 & 9848 & 4787 & 18767 & 31233 & 11101 & 374048 \\
\hline Animal Barns & All* & 42 & 5038 & -1945 & 12021 & 9202 & 3221 & 22268 & 7874 & 3067 & 186468 \\
\hline Silage Grass & All* & 20 & 901 & -2760 & 4561 & 527 & 215 & 1143 & 1153 & 361 & 46231 \\
\hline
\end{tabular}

* All measurements for the yearlong study are combined into one group 
590 Table 7 Farm scale $\mathrm{N}_{2} \mathrm{O}$ inventories are calculated for each of the four seasonal measurement periods using

591 three statistical methods. Flux contributions are split between extensive arable and grazing fields and the areas

592 of the farm in which specific $\mathrm{N}_{2} \mathrm{O}$ flux altering features were present (units in $\mathrm{g} \mathrm{N}_{2} \mathrm{O}-\mathrm{N} \mathrm{h}^{-1}$ ).

\begin{tabular}{|c|c|c|c|c|c|c|c|c|c|c|}
\hline Season & Source categories & $\begin{array}{l}\text { Naive } \\
\text { Method } \\
\text { Mean Flux }\end{array}$ & $\begin{array}{l}95 \% \\
\text { C.I. } \\
\text { Lower } \\
\end{array}$ & Upper & $\begin{array}{l}\text { Bayesian } \\
\text { Method } \\
\text { Mean Flux } \\
\end{array}$ & $\begin{array}{l}95 \% \\
\text { C.I. } \\
\text { Lower } \\
\end{array}$ & Upper & $\begin{array}{l}\text { Zou's } \\
\text { Method } \\
\text { Mean Flux }\end{array}$ & $\begin{array}{l}95 \% \\
\text { C.I. } \\
\text { Lower } \\
\end{array}$ & Upper \\
\hline \multirow[t]{2}{*}{ Autumn } & Majority fields & 50 & -212 & 312 & 15 & 8 & 25 & 21 & 12 & 77 \\
\hline & Total & 61 & -201 & 323 & 31 & 18 & 55 & 42 & 28 & 9367 \\
\hline Winter & Majority fields & 5 & -2 & 12 & 6 & 3 & 10 & 3 & 2 & 5 \\
\hline \multirow[t]{3}{*}{ Spring } & Majority fields & 117 & -226 & 460 & 81 & 60 & 111 & 94 & 71 & 155 \\
\hline & Feature areas & 8 & -7 & 23 & 10 & 5 & 18 & 22 & 11 & 9344 \\
\hline & Total & 125 & -218 & 468 & 91 & 70 & 122 & 117 & 91 & 9439 \\
\hline
\end{tabular}

